\title{
Initial Experience with Laparoscopic Nephrectomy at Services Hospital Lahore
}

${ }^{1}$ Muhammad Farooq, ${ }^{1}$ AtharMahmood, ${ }^{2}$ Hamza Farooq, ${ }^{1}$ Bilal Ikram Khan, ${ }^{1}$ Muhammad Shahzad Anwar

${ }^{1}$ Department of Urology \& Kidney Transplant, Services Institute of Medical Sciences, Lahore

${ }^{2}$ Undergraduate Medical Student, Services Institute of Medical Sciences, Lahore

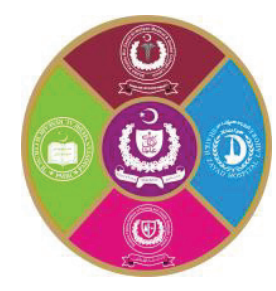

\begin{abstract}
Introduction: Nephrectomy means removal of kidney. Laparoscopic nephrectomy is an effective way to remove a diseased or cancerous kidney. Nephrectomy is performed to treat malignant or benign tumors of the kidney and symptomatic non functioning kidney. Laparoscopic nephrectomy is performed through transperitoneal or retroperitoneal approach. Aims \& Objectives: To determine the initial experience of laparoscopic nephrectomy. Place and duration of study: Department of Urology, Services Hospital, Lahore from $1^{\text {st }}$ January 2018 to $30^{\text {th }}$ June 2019 . Material \& Methods: A total of 50 patients who underwent laparoscopic nephrectomy were included. The demographic data like age, gender, site of operation, operative time, conversion rates, postoperative complications and postoperative hospital stay were recorded. Data was analyzed using SPSS 20.0 and reported as mean \pm s.d, frequencies and percentages. Results: There were 28 $(56 \%)$ female patients and $22(44 \%)$ male patients. Six $(12 \%)$ patients were ages $<25$ years, $20(40 \%)$ were ages 25 to 40 years, $18(36 \%)$ were ages 41 to 55 years and $6(12 \%)$ were ages above 55 years. Nonfunctional kidney due to stone disease was the most common indication $35(70 \%)$. Mean operative time was $170.43+8.45$ minutes. Conversion rate was in $1(2 \%)$ patients. Mean hospital stay was $4.32 \pm 1.45$ days. Conclusion: It is concluded from this study that laparoscopic nephrectomy is safe and better technique with very low rate of complications.
\end{abstract}

Key words: Non-functional kidney, Nephrectomy, Laparoscopic, Outcomes.

\section{INTRODUCTION}

$\mathrm{N}$ ephrectomy means removal of kidney, laparoscopic nephrectomy is an effective way to remove a diseased or cancerous kidney. ${ }^{1}$ Nephrectomy is performed to treat malignant or benign tumors of the kidney, or severe unilateral parenchymal damage from nephrosclerosis, pyelonephritis, reflux, or congenital dysplasia. Nephrectomy can be performed through open or laparoscopic procedure. ${ }^{2}$ During the $20^{\text {th }}$ century, most nephrectomies for benign and malignant renal disease were performed by an open approach. ${ }^{3}$ There has been widespread interest in urologic laparoscopy since the first total laparoscopic nephrectomy was performed by Clayman in $1990 .{ }^{4}$ Laparoscopic nephrectomy is performed through transperitoneal or retroperitoneal approach. When compared with an open procedure, many surgeons find that laparoscopic nephrectomy offers shorter length of hospital stay, shorter time to oral intake, less pain medication requirement, earlier return to work and daily activities, a more favorable cosmetic result and outcomes identical to that of open surgery. ${ }^{5,8}$ The procedures have similar complication and cancer-control rates. Numerous studies have documented longer operative time for laparoscopic approaches; however, with surgeon experience, operative times may even be shorter than with open techniques. ${ }^{9}$

Present study was conducted aimed to examine the initial experience of laparoscopic nephrectomy and determine the outcomes such as conversion rates, postoperative complications and postoperative hospital stay.

\section{MATERIAL AND METHODS}

This prospective descriptive study was conducted at Department of Urology Hospital Services Hospital Lahore from $1^{\text {st }}$ January 2018 to $30^{\text {th }}$ June 2019 for a period of 1.5 years. A total of 50 patients of both genders with ages 18 to 70 years were included in this study. Patients detailed demographics including age, gender, indications and operation site was recorded after taking informed consent. Patient with history of previous multiple surgeries in the same 
side, history of laparotomy and patient refusal for laparoscopy were excluded.

All patients had undergone laparoscopic nephrectomy through transperitoneal approach under general anesthesia. Outcomes such as operative time, conversion rate, need for blood transfusion, postoperative complications and postoperative hospital stay were recorded.

\section{Statistical analysis:}

All the data was analyzed by SPSS 20.0. Mean SD was applied. Frequencies and percentages were obtained.

\section{RESULTS}

Out of 50 patients $28(56 \%)$ patients were females and $44 \%$ patients were male. $6(12 \%)$ patients were ages $<25$ years, $20(40 \%)$ were ages 25 to 40 years, $18(36 \%)$ were ages 41 to 55 years and $6(12 \%)$ were ages above 55 years. Non-functional kidney due to stone disease was the most common cause of nephrectomy 35 (70\%) followed by PUJ obstruction $10(20 \%)$, chronic pyelonephritis $3(6 \%)$ and others $2(4 \%)$. Thirty $(60 \%)$ patients had right site nephrectomy and $20(40 \%)$ patients had left site of operation (Table-1).

Mean operative time was $170.43 \pm 8.45$ minutes. Two (4\%) patients need blood transfusion, $1(2 \%)$ patient had conversion to open nephrectomy, mean hospital stay $4.32 \pm 1.45$ days. One $(2 \%)$ patient had wound infection. No mortality was recorded (Table2)

\begin{tabular}{|c|c|c|}
\hline Variable & No. & $\%$ \\
\hline \multicolumn{3}{|l|}{ Gender } \\
\hline Male & 22 & 44.0 \\
\hline Female & 28 & 56.0 \\
\hline \multicolumn{3}{|l|}{ Age (years) } \\
\hline$<25$ & 6 & 12.0 \\
\hline $25-40$ & 20 & 40.0 \\
\hline $41-55$ & 18 & 36.0 \\
\hline$>55$ & 6 & 12.0 \\
\hline \multicolumn{3}{|l|}{ Indications } \\
\hline Due to Stone & 35 & 70.0 \\
\hline Due to PUJ Obstructions & 10 & 20.0 \\
\hline Chronic Pyelonephritis & 3 & 6.0 \\
\hline Others(small renal tumors) & 2 & 4.0 \\
\hline \multicolumn{3}{|l|}{ Site } \\
\hline Right & 30 & 60.0 \\
\hline Left & 20 & 40.0 \\
\hline
\end{tabular}

Table-1: Demographic information of the patients

\begin{tabular}{|l|c|c|}
\hline Outcome & No. & \% \\
\hline $\begin{array}{l}\text { Mean operative time } \\
\text { (minutes) }\end{array}$ & $170.43 \pm 8.45$ & \\
\hline Blood transfusion & 2 & 4.0 \\
\hline Conversion to open & 1 & 2.0 \\
\hline Wound infection & 1 & 2.0 \\
\hline $\begin{array}{l}\text { Mean hospital } \\
\text { stay(days) }\end{array}$ & $4.32 \pm 1.45$ & \\
\hline
\end{tabular}

Table-2: Outcomes recorded after Laparoscopic nephrectomy

\section{DISCUSSION}

Laparoscopic nephrectomy is commonly performed surgical minimally invasive procedure in urology settings with better outcomes and lesser complications rate. ${ }^{10,11}$ Laparoscopic nephrectomy is associated with a long learning curve for surgeons and at the same time in start bit lengthy operative time. Looking at the published literature one of the recent study published in which it was mentioned that although the operative time was 22 min more in laparoscopic nephrectomy group as compared to open surgery but there was decreased post op pain and decreased hospital stay. ${ }^{12}$ Many of studies had been conducted to determine the outcomes of laparoscopic nephrectomy for non-functional kidney disease and benign renal disorders and they reported less hospital stay, low rate of conversion with better cosmetic results. ${ }^{13,14}$ The present study aimed to examine the outcomes of laparoscopic nephrectomy in our institution. During the study period 50 patients had received laparoscopic nephrectomy due to non-functional kidney disease and small renal tumors. In our study majority of patients were females $56 \%$ followed by male $44 \%$. A study conducted by Khan MM et a ${ }^{15}$ regarding outcomes of laparoscopic nephrectomy in which they reported male patients was high in numbers as compared to females $53.3 \%$ vs $46.7 \%$.

In our study we found $6(12 \%)$ patients were ages $<25$ years, $20(40 \%)$ were ages 25 to 40 years, 18 (36\%) were ages 41 to 55 years and $6(12 \%)$ were ages above 55 years. These results were similar to some other studies in which majority of patients were ages 30 to 50 years. ${ }^{16}$ In this study the most common cause of nephrectomy was non-functional kidney due to stone disease found in $35(70 \%)$ patients followed by PUJ obstruction 10 (20\%), chronic pyelonephritis $3(6 \%)$ and small renal tumors 2 (4\%). A study by Nareshet $a l^{17}$ reported PUJ obstruction was the most common etiology of nephrectomy. 
In present study the mean operative time was $170.43+8.45$ minutes. Many of studies reported less operative time for laparoscopic nephrectomy as compared to open surgery. ${ }^{18,19}$ In our study $2(4 \%)$ patients need blood transfusion, $1(2 \%)$ patient had conversion to open nephrectomy, mean hospital stay $4.32 \pm 1.45$ days. One $(2 \%)$ patient had wound infection. No mortality was recorded. These results were similar to many other studies in which patients treated with laparoscopic nephrectomy had less conversion rate, less blood loss and less hospital stay as compared to conventional open surgical procedure. ${ }^{20,21}$

\section{CONCLUSION}

Laparoscopic nephrectomy considered as a safe and very effective treatment procedure with very low rate of complications. In view of the inherent benefits for patients, in terms of reduced pain, faster recovery, improved cosmetic results and shorter hospital stay, the laparoscopic approach has become the standard approach for nephrectomy in our institution.

\section{REFERENCES}

1. Haque I, Subramanian A, Huang $\mathrm{CH}$, Godwin AK, Van Veldhuizen PJ, Banerjee S, et al. The Role of compounds derived from natural supplement as anticancer agents in renal cell carcinoma: a review. Int JMolSci.2018;19(1):10

2. Arabsalmani M, Mohammadian-Hafshejani A, Ghoncheh M, Hadadian F, Towhidi F, Vafaee $\mathrm{K}$, et al. Incidence and mortality of kidney cancers, and human development index in Asia; a matter of concern. J Nephropathol. 2017; $6(1): 30-42$

3. Mohammadian M, Pakzad R, Towhidi F, Makhsosi BR, Ahmadi A, Salehiniya H. Incidence and mortality of kidney cancer and its relationship with HDI (Human Development Index) in the world in 2012. Clujul Med 2017; 90(3):286-93.

4. Clayman RV, Kavoussi LR, Soper NJ, Dierks SM, Merety KS, Darcy MD, et al. Laparoscopic nephrectomy: initial case report. J Urol. 1991; 146:278-82.

5. Campbell S, Uzzo RG, Allaf ME, Bass EB, Cadeddu JA, Chang A,et al. Renal mass and localized renal cancer: AUA guideline. J Urol 2017; 198(3):520-9.

6. Gill IS, Schweizer D, Hobart MG, Sung GT, Llein E, Novick AC. Retroperitoneal laparoscopic radical nephrectomy: the
Cleveland clinic experience. J Urol. 2000; 163:1665-70.

7. Clayman RV, Kavoussi LR, Soper NJ, Dierks SM, Meretyk S, Darcy MD, et al. Laparoscopic nephrectomy: initial case report. J Urol 2017; 197(25): S182-6.

8. Campbell SC, Lane BR. Malignant renal tumors. In: Wein AJ, Kavoussi LR, Novick AC, Partin AW, Peter CA, eds. Campbell-Walsh urology. $10^{\text {th }}$ ed. $\quad$ Philadelphia: Saunders Elsevier; 2012, 1420.

9. Kwon SY, Jung JW, Kim BS, Kim TH, Yoo ES, Kwon TG, et al. Laparoscopic versus open radical nephrectomy in $\mathrm{T} 2$ renal cell carcinoma: Long-term oncologic outcomes. Korean J Urol 2011; 52:474-8.

10. Laird A, Choy KCC, Delaney H, Cutress ML, O'Connor KM, Tolley DA, et al. Matched pair analysis of laparoscopic versus open radical nephrectomy for the treatment of T3 renal cell carcinoma. World JUrol. 2015; 33(1):25-32.

11. Benoit T, Peyronnet B, Roumiguié M, Verhoest G, Beauval JB, Delreux A, et al. Laparoscopic nephrectomy for polycystic kidney: comparison of the transperitoneal and retroperitoneal approaches. World JUrol. 2016;34(7):901.

12. Jain S, Jain SK, Kaza RC, Sing Y. This challenging Procedure has successful outcomes; Laparoscopic Nephrectomy in inflammatory Renal diseases. UrolAnn. 2018;10:35-40.

13. Lee C, You D, Yoo S, Song C, Hong B, Hong $\mathrm{JH}$, et al. Oncological outcomes of patients with incidental pathological T3a stage small renal cell carcinoma after partial nephrectomy. JCancer Res Clin Oncol. 2016; 142(7):1651-7.

14. Khan MM, Patel RA, Jain N, Balakrishnan A, Venkataraman M. Prospective analysis of laparoscopic versus open radical nephrectomy for renal tumours more than $7 \mathrm{~cm}$. J Min Access Surg. 2019; 15:14-8.

15. Bansal P, Kumar A, Shrivastava A, Kumar D, Mandhani A, Bhandari M. Laparoscopic radical nephrectomy: Our initial experience. Indian $\mathrm{J}$ Urol. 2004; 20:154-9.

16. Giri NK, Thapa N, Thapa BK, Bhandari BB, Hamal BK. Outcome of laparoscopic nephrectomy in benign renal disease. JPAHS. 2016; 3(2):19-22.

17. Guo $\mathrm{P}, \mathrm{Xu} \mathrm{W}, \mathrm{Li} H$, Ren $\mathrm{T}$, Ni S, Ren M. Laparoscopic nephrectomy versus open nephrectomy for patients with autosomal dominant polycystic kidney disease: a systematic review and meta-analysis. PLoS One 2015; 10:e129317. 
18. Lim KS, Tay S, Gostelow M, Fook-Chong $\mathrm{SMC}, \mathrm{Ng}$ LG. Does size really matter? A retrospective analysis of donor renal volume and its effects on renal function in donors after donation. J Biomed Graphics Comput. 2016; 6:14-21.

19. Tan WS, Berg S, Cole AP, Krimphove M, Marchese M, Lipsitz SR, et al. Comparing longterm outcomes following radical and partial nephrectomy for ct1 renal cell carcinoma in young and healthy individuals: JNCI Cancer Spectrum 2019; 3(1): e1423-4.

20. Jain S, Jain SK, Kaza RC, Singh Y. This challenging procedure has successful outcomes: Laparoscopic nephrectomy in inflammatory renal diseases. Urol Ann 2018; 10:35-40.

21. Verhoest G, Delreux A, Mathieu R, Patard JJ, Vigneau C, Rioux-Leclercq $\mathrm{N}$, et al. Transperitoneal laparoscopic nephrectomy for autosomal dominant polycystic kidney disease. JSLS. 2012; 16:437-42.

\section{The Authors:}

Dr. Muhammad Farooq

Associate Professor,

Department of Urology and Kidney Transplant,

Services Institute of Medical Sciences, Lahore.
Dr. Athar Mahmood

Assistant Professor,

Department of Urology and Kidney Transplant, Services Institute of Medical Sciences, Lahore.

\section{Hamza Farooq}

Undergraduate Medical Student,

Services Institute of Medical Sciences, Lahore.

Dr. Bilal Ikram Khan

Postgraduate Trainee,

Department of Urology and Kidney Transplant,

Services Institute of Medical Sciences, Lahore.

Dr. Muhammad Shahzad Anwar

HOD, Urology and Kidney Transplant,

Services Institute of Medical Sciences, Lahore.

\section{Corresponding Author:}

Dr. Athar Mahmood

Assistant Professor,

Department of Urology and Kidney Transplant, Services Institute of Medical Sciences, Lahore.

E-mail:athar132@yahoo.com 